\title{
Dysfunctional Homozygous VRK1-D263G Variant Impairs the Assembly of Cajal Bodies and DNA Damage Response in Hereditary Spastic Paraplegia
}

Patricia Morejon-Garcia, MSc, Boris Keren, PhD, Iñigo Marcos-Alcalde, PhD, Paulino Gomez-Puertas, PhD, Fanny Mochel, MD, PhD, and Pedro. A. Lazo, MD, PhD

Neurol Genet 2021;7:e624. doi:10.1212/NXG.0000000000000624

\author{
Correspondence \\ Dr. Lazo \\ pedro.lazo@csic.es
}

\section{Abstract}

\section{Background and Objectives}

To conduct a genetic and molecular functional study of a family with members affected of hereditary spastic paraplegia (HSP) of unknown origin and carrying a novel pathogenic vaccinia-related kinase 1 (VRK1) variant.

\section{Methods}

Whole-exome sequencing was performed in 2 patients, and their parents diagnosed with HSP. The novel VRK1 variant was detected by whole-exome sequencing, molecularly modeled and biochemically characterized in kinase assays. Functionally, we studied the role of this VRK1 variant in DNA damage response and its effect on the assembly of Cajal bodies (CBs).

\section{Results}

We have identified a very rare homozygous variant VRK1-D263G with a neurologic phenotype associated with HSP and moderate intellectual disability. The molecular modeling of this VRK1 variant protein predicted an alteration in the folding of a loop that interferes with the access to the kinase catalytic site. The VRK1-D263G variant is kinase inactive and does not phosphorylate histones $\mathrm{H} 2 \mathrm{AX}$ and $\mathrm{H} 3$, transcription factors activating transcription factor 2 and $\mathrm{p} 53$, coilin needed for assembly of CBs, and p53 binding protein 1, a DNA repair protein. Functionally, this $V R K 1$ variant protein impairs $\mathrm{CB}$ formation and the DNA damage response.

\section{Discussion}

This report expands the neurologic spectrum of neuromotor syndromes associated with a new and rare VRK1 variant, representing a novel pathogenic participant in complicated HSP and demonstrates that $\mathrm{CBs}$ and the DNA damage response are impaired in these patients.

\footnotetext{
From the Molecular Mechanisms of Cancer Program (P.M.-G., P.A.L.), Instituto de Biología Molecular y Celular del Cáncer, Consejo Superior de Investigaciones Científicas (CSIC) Universidad de Salamanca; Instituto de Investigación Biomédica de Salamanca (IBSAL) (P.M.-G., P.A.L.), Hospital Universitario de Salamanca, Spain; Genetics Department (B.K.), La Pitié-Salpêtrière Hospital, APHP. Sorbonne Université, Paris, France; Molecular Modelling Group (I.M.-A.), Centro de Biología Molecular "Severo Ochoa". CSIC - Universidad Autónoma de Madrid, Spain; Biosciences Research Institute (I.M.-A., P.G.-P.), School of Experimental Sciences, Universidad Francisco de Vitoria, Madrid, Spain; and Sorbonne Université Université Pierre et Marie Curie (F.M.), Institut du Cerveau et de la Moelle épinière, INSERM U-1127, CNRS-UMR 7225, Paris, France.

Go to Neurology.org/NG for full disclosures. Funding information is provided at the end of the article.

P. Morejon-Garcia and B. Keren are equal co-first authors. F. Mochel and P. A. Lazo are equal co-senior authors.
}

The Article Processing Charge was funded by CSIC.

This is an open access article distributed under the terms of the Creative Commons Attribution-NonCommercial-NoDerivatives License 4.0 (CC BY-NC-ND), which permits downloading and sharing the work provided it is properly cited. The work cannot be changed in any way or used commercially without permission from the journal. 


\section{Glossary}

53BP1 = p53 binding protein 1; ALS = amyotrophic lateral sclerosis; ATF2 = activating transcription factor 2; CB = Cajal body; CMT = Charcot-Marie-Tooth; HA = hemagglutinin; HSP = hereditary spastic paraplegia; $\mathbf{M D}=$ molecular dynamics; mVRK1 = murine VRK1; PCH1 = pontocerebellar hypoplasia; PDB = Protein Data Bank; SMA = spinal muscular atrophy; SMN = survival of motorneuron; VRK1 = vaccinia-related kinase 1 ; WES = whole-exome sequencing.

Human voluntary movements are under control of the pyramidal motor system. Motor neuropathies are a heterogeneous group of motor neuron diseases that share some common characteristics, but differ in their clinical presentation and severity. Among these diseases are CharcotMarie-Tooth (CMT), spinal muscular atrophy (SMA), amyotrophic lateral sclerosis (ALS), and hereditary spastic paraplegia (HSP). These diseases have a genetic origin, but the genes implicated are heterogeneous. Patients with HSP, also known as Strumpell-Lorrain syndrome, present lower limb spasticity, muscle weakness, and neurogenic bladder. However, patients may also present additional neurologic and non-neurologic symptoms. ${ }^{1}$ Patients with HSP share axon degeneration, mainly in the thoracic and distal spinal cord, and a reduced affectation of the cervical cord, implying affectations of both motor neurons with different degrees of severity. ${ }^{2}$ HSP has a low frequency, between 3 and 10/ 100,000 depending on the population, and has been associated with mutations or gene variants in at least 73 different genes. $^{1,3}$

Recently a novel gene, vaccinia-related kinase 1 (VRK1), has been associated with motor neuron diseases that present a significant heterogeneity. They include several of the clinical phenotypes associated with motor neurons, including SMA, ${ }^{4-6}$ ALS, ${ }^{7}$ and Charcot-Marie Tooth. ${ }^{8,9}$ Functionally, the VRK1 gene is implicated in the regulation of cell proliferation, ${ }^{10,11}$ transcription, ${ }^{12-14}$ autophagy, ${ }^{15}$ chromatin compaction, ${ }^{16,17}$ DNA damage responses, ${ }^{18,19}$ Cajal body (CB) stability and assembly, ${ }^{20-22}$ and neuronal migration. ${ }^{23}$ Most of the known VRK1 mutants are very uncommon variants in the population, which are recessive, and their neurologic phenotype is only detected in either homozygous or compound heterozygous individuals. However, the pathogenic role of VRK1 variants in neurologic diseases is not yet understood, but it may represent either a specific subtype of these diseases or alternatively a pathogenic mechanism common to all of them. In this work, we have studied a case of complicated HSP that expands the neurologic phenotypes associated with VRK1 mutations in motor neuron diseases.

\section{Methods}

\section{Standard Protocol Approvals, Registrations, and Patient Consents}

Informed consent forms were signed by participating individuals, and all procedures performed in studies involving human participants were in accordance with the ethical standards of the Ethical Board of the La Pitié-Salpêtrière Hospital (Paris, France) and adhere to the ethical standards laid down in the 1964 Declaration of Helsinki and its later amendments. The CARE reporting guidelines were used.

\section{Data Availability}

The VRK1 mutation is available in ClinVar with the ID (accession number: SCV001478444). Because of their sensitive nature, genomic data sets generated in this study are available from the corresponding author on request, given that the request is not in conflict with French General Data Protection Regulations.

Genome Aggregation Database (gnomAD), gnomad.broadinstitute.org/.

Polymorphism Phenotyping v2 (PolyPhen2), genetics.bwh. harvard.edu/pph2/.

\section{Whole-Exome Sequencing}

Whole-exome sequencing (WES) was performed in the family trio (patients and both parents) for diagnostic purposes due to the unknown origin of the disease. Library preparation, sequencing was performed according to the manufacturer protocol (Roche Technologies). Exons were captured using the SeqCap EZ MedExome kit (Roche Technologies), and the sequence was generated on a NextSeq 500 instrument (Illumina Inc). For data analysis, raw reads were mapped to the human reference genome GRCh37 using the Burrow-Wheeler aligner (v0.717). The resulting binary alignment/map files were further processed by genome analysis tool kit haplotypecaller (v3.8). The variant call format files were then annotated on Snpeff version $4.3 \mathrm{~T} .{ }^{24}$ Only coding nonsynonymous and splicing variants were considered. Variant prioritization was conducted thanks to the transmission mode (de novo, autosomal recessive, and $\mathrm{X}$ linked) and the frequency of the variants in the gnom $A D$ database 16. The variant identified was confirmed by Sanger sequencing using the following primers: forward: $5^{\prime}$-GCTAGAAGTTAATTGGGAGGTAAGC-3'; and reverse: $5^{\prime}$ TGTGCTACATCCTAAATATGCTTAC-3'. Polymorphism Phenotyping v2 (PolyPhen2), genetics.bwh.harvard.edu/pph2/.

\section{Molecular Dynamics Simulation of Human VRK1-D263G}

The 3D structure of the human VRK1 wild-type protein (UniprotKB id: Q99986) was obtained from the Protein Data Bank (PDB id: 2LAV). The conformer no. 16 (of the 20 
NMR conformers included in the PDB file) was selected for further processing. The model for VRK1-G263 variant was generated using the wild-type structure as template and standard homology modeling methods. Structures for the wild-type and variant proteins were subjected to $200 \mathrm{~ns}$ of unrestrained molecular dynamics (MD) simulation, essentially as previously described. ${ }^{25}$ The full modeling and MD methods are described in eMethods, links.lww.com/NXG/ A468.

\section{VRK1 Gene, Plasmids, and Mutagenesis}

Human VRK1 was expressed from mammalian expression vector, pCEFL-hemagglutinin (HA)-VRK1, ${ }^{26}$ and bacterial expression plasmid-glutathione S-transferase expression-4TVRK1. ${ }^{22,26-28}$ The D263G mutation was introduced in these plasmids with the GeneArt Site-Directed Mutagenesis System (Invitrogen-Thermo Fisher). The primers to generate human VRK1-D263G were forward (5'-CTTCCTTGG GAGGGTAATTTGAA- $\left.{ }^{\prime}\right)$ and reverse (5'-ATCTTTCAAATTACCCTCCCAAG-3'). The human D263G mutation was also introduced in murine VRK1 (mVRK1) cDNA and cloned in pCEFL-Myc-mVRK1 to generate pCEFL-MycmVRK1-D263G plasmid for use in transfection experiments. The primers used to generate the mVRK1-D263G were forward (5'-CTTCCTTGGGAAGGTAACTTGAAA- $\left.3^{\prime}\right)$ and reverse ( $5^{\prime}$-ATCTTTCAAGTTACCTTCCCAAGG-3'). This mutation was also introduced in $\mathrm{mVRK} 1$ to generate a lentiviral expression construct, plasmids pLenti-C-HA-IRESBSD-mVRK1-D263G that was used for the generation of stable cells lines expressing the murine gene for use in rescue experiments. Control plasmids expressing murine kinaseactive (pLenti-C-HA-IRES-BSD-mVRK1) and kinase-dead (K179E) (pLenti-C-HA-IRES-BSD-mVRK-K179E) have already been reported. ${ }^{8,22}$ Full methods and plasmids coding used for some substrates are described in eMethods, links. lww.com/NXG/A468.

\section{Kinase Assays}

Kinase assays were performed as previously described. ${ }^{22,26}$ Briefly, in vitro kinase assays with [32-P]- $\gamma$ ATP were performed with glutathione S-transferase-VRK1 wild-type or the VRK1-D263G variant. $^{20,22}$

In vitro kinase assays with the histone $\mathrm{H} 3^{17,28}$ and $\mathrm{H} 2 \mathrm{AX},{ }^{17}$ $\mathrm{p} 53,{ }^{13,29,30}$ p53 binding protein 1 (53BP1), ${ }^{18,31}$ activating transcription factor 2 (ATF2), ${ }^{12}$ or coilin ${ }^{20}$ as substrates were previously published. Kinase-dead VRK1 (K179E) was used as negative control in the assays. ${ }^{8,22}$ All plasmids were transfected in BL21 E coli to express and purify the fusion protein used as substrate in kinase assays. Full methods are in Supplementary eMethods, links.lww.com/NXG/A468.

\section{Cell Lines, Transfections, and Protein Analysis}

All molecular and cellular methods have been reported before $^{22}$ and are detailed in Supplementary eMethods, links. lww.com/NXG/A468. The antibodies used in this work are described in eTable 1, links.lww.com/NXG/A469.

\section{Results}

\section{Clinical Presentation of the Patients Carrying the Novel VRK1-D263G Mutation}

The 2 cases under study belong to a family from Senegal. The parents are first cousins and have 6 children, 2 affected women with a progressive neuromotor disease and 4 healthy children-although 2 were born prematurely. Noticeably, the mother had 4 late miscarriages in Senegal, from unknown causes. Both patients were born in Senegal.

Patient 1 is a 29-year-old woman. Pregnancy and delivery were reportedly uneventful. She presented with psychomotor development and started to walk at age 2.5 years. Her gait became spastic at about age 5 years, and she developed dysarthria in late adolescence. She stopped attending school at age 10 years.

At examination at age 21 years, she walked without aid, but her gait was clearly spastic with flessum of the knee. The Romberg test was negative. She had decreased proximal muscle strength of her lower limbs (iliopsoas 3/5 and gluteus medius 4/5) but normal muscle strength of the upper limbs. She had brisk reflexes of the 4 limbs with bilateral Babinski sign, nonsustained clonus, and spastic equinus feet. There was moderate vibration loss at the ankles and mild dysarthria.

Brain MRI detected a minimal cerebellar atrophy. Spine MRI, nerve conduction studies, CSF standard analyses, EEG, fundoscopy, and visual and auditory evoked potentials were all normal. Neuropsychological testing revealed moderate intellectual disability and dysexecutive functions. Metabolic tests (plasma folate, B12 and homocysteine, plasma amino acid and urine organic acid chromatography, plasma verylong-chain fatty acids, phytanic and pristanic acids, plasma cholestanol, and 25- and 27-hydroxycholesterol) were normal. A gene panel for HSP (74 genes) did not identify any pathogenic variant. Clinical examination has been stable over 8 years.

Patient 2 is a 25 -year-old woman. Pregnancy and delivery were reportedly uneventful. Information regarding early milestones was not available. There was a history of epileptic seizures in infancy, but not documented. The onset of spastic gate occurred at age 8 years, and the patient developed signs of a neurogenic bladder in her twenties. At first examination at age 17 years, she presented with spastic gait with flessum of the knee, but could walk without aid. The Romberg test was negative. She had mild decreased proximal muscle strength of her lower limbs (iliopsoas $4 / 5$ and gluteus medius $4 / 5$ ). She displayed brisk reflexes of the 4 limbs with bilateral Babinski and Hoffmann signs, nonsustained clonus, and mild spastic equinus feet. There was mild vibration loss at the ankles.

Brain MRI, nerve conduction studies, EEG, fundoscopy, visual evoked potentials, and electroretinogram were all normal. Neuropsychological testing revealed moderate intellectual disability and dysexecutive functions. Metabolic tests (plasma 
folate, B12 and homocysteine, plasma amino acid and urine organic acid chromatography, plasma very-long-chain fatty acids, phytanic and pristanic acids, plasma cholestanol, and 25- and 27-hydroxycholesterol) were normal. A gene panel for HSP (74 genes) did not identify any pathogenic variant.

Clinical follow-up was remarkable for the occurrence of mouth ulcers, arthralgia, and Raynaud syndrome and elevated creatine kinase (between 1,500 and 3,000 U/L). Further tests revealed myositis, mild pericarditis, polyclonal hypergammaglobulinemia, and antinuclear antibodies, which led to the diagnosis of mixed connective tissue. The patient was treated with hydroxychloroquine with clinical benefit.

\section{Detection of Homozygous VRK1-D263G Variant}

To identify the candidate gene that might be implicated in this phenotype, a diagnostic WES study was performed. The WES study detected in both patients a homozygous missense variant, NM_003384.2:c.788A>G Chr14(GRCh37):g.97322545A>G p.(Asp263Gly). This amino acid change (D263G) has a very low frequency $(3.98 \mathrm{e}-6)$ in the human population based on gnom $\mathrm{AD}$ database. The parents are first cousins and asymptomatic heterozygous carriers. This variant was confirmed by Sanger sequencing (eFigure 1, links.lww.com/NXG/A466).

\section{Molecular Dynamics Simulation of the VRK1-D263G Variant}

The wild-type and mutant proteins were analyzed using MD simulation techniques. To study the structural and functional implications of the missense VRK1 variant D263G, we used the 3D structure of the human VRK1 wild-type protein that was obtained from the PDB (id: 2LAV). In the case of the wild-type protein VRK1-D263, quickly after the beginning of the simulation, the amino acid Asp263 establishes a salt bridge with the amino acid Arg3 in the N-terminal end of the protein, which, together with the adjacent Lys5 residue, forms a positively charged patch. The contact formed between the negatively charged Asp263 and the positively charged amino acids of the amino-terminus of the VRK1 protein remains stable along most of the trajectory. The N-term loop is then located near the active center of the protein, probably regulating its activity or substrate accessibility in some way (Figure 1, left).

Figure 1 Molecular Effect of the D263G Substitution on the VRK1 Protein

A. VRK1_wt (D263)

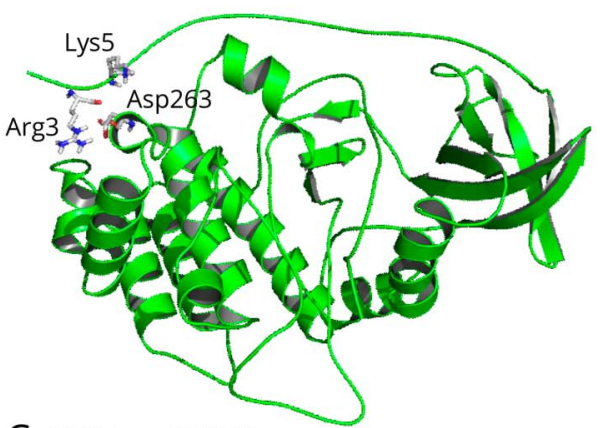

C. VRK1_wt (D263)

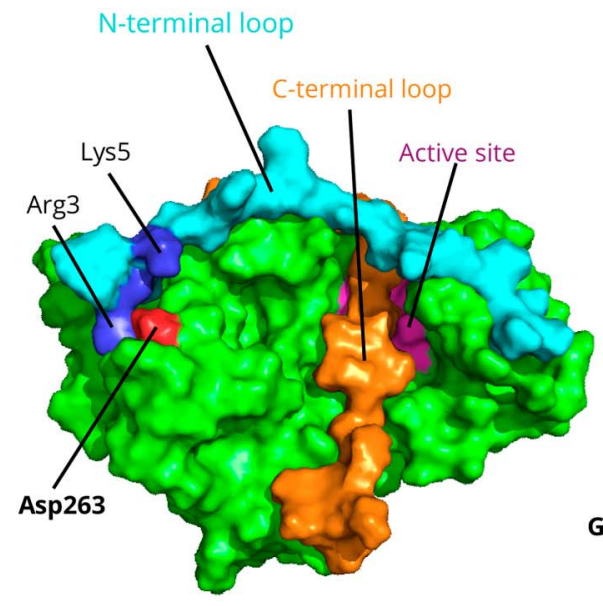

B. VRK1_G263

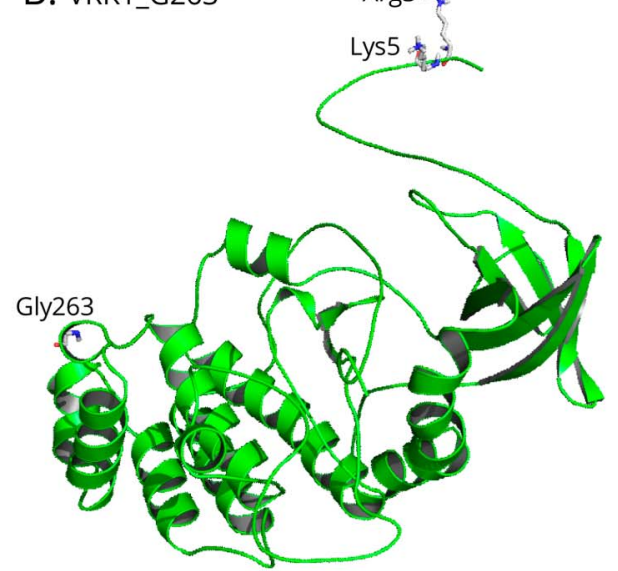

D. VRK1_G263

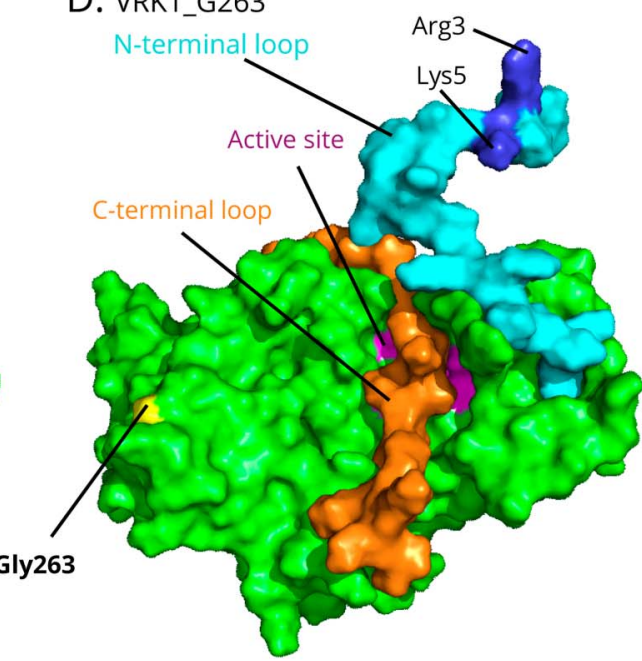

Three-dimensional representation of the protein model showing the elements of the secondary structure of VRK1 (A) and VRK1-D263G (B). The Nterminal region bends and interacts by Arg3 and Lys5 with D263 in the wildtype protein. The mutant D263G mutant impairs this interaction with the $\mathrm{N}$ terminus. ( $C$ and $D$ ) Three-dimensional representation of the protein surface on the secondary structure of VRK1 (C) and variant VRK1-D263G (D). VRK1 = vaccinia-related kinase 1. 
The behavior of the VRK1-D263G mutant protein is very different in the MD simulation. Gly263 does not establish a stable bond with the amino acids Arg3 or Lys5 in the aminoterminus end; thus, the VRK1 N-term loop acquires a completely different structural conformation, which can alter the regulation of the activity or accessibility of substrates to the active center (Figure 1, right) impairing its functionality.

\section{The VRK1-D263G Protein Is a Loss-of-Function Variant}

To determine the consequences of this amino acid change in the VRK1 protein, we performed in vitro kinase activity and protein stability assays. These VRK1 substrates included $\mathrm{p} 53,{ }^{13}$ histones $\mathrm{H} 3{ }^{16,28}$ and $\mathrm{H} 2 \mathrm{AX},{ }^{17,19}$ 53BP1 that is involved in DNA repair, ${ }^{18,31}$ coilin that is the structural scaffold protein of $\mathrm{CBs},{ }^{32,33}$ and ATF2, ${ }^{12}$ which can affect motor neuron degeneration ${ }^{34}$ and axonal transport. ${ }^{35}$ All these VRK1 substrates were phosphorylated by the wild-type VRK1, but not by the VRK1-D263G variant nor the kinasedead VRK1-K179E (Figure 2), which was used as a negative control.

In addition, we also tested whether the stability of VRK1D263G protein was altered. For this aim, cells were transfected with HA-tagged VRK1 constructs and treated with cycloheximide to block translation. A time curve was performed with the wild-type VRK1, the variant VRK1-D263G, and the kinase-dead VRK1-K179E ${ }^{14,36}$ proteins. The wildtype and the variant proteins were equally stable, whereas the kinase-dead VRK1-K179E was unstable (eFigure 2, links.lww. com/NXG/A467) as predicted. ${ }^{10}$
VRK1-D263G Loss-of-Function Variant Impairs the Assembly of CBs

CBs are assembled on coilin, ${ }^{37}$ which is regulated by its direct phosphorylation on Ser184 mediated by VRK1. ${ }^{20,33}$ To study the effect that the VRK1-D263G variant has on the assembly of $\mathrm{CBs}$, detected by coilin aggregation, we performed recue experiments in Hela cells in which the endogenous human VRK1 was depleted and replaced by transfection using plasmids expressing either the mVRK1 or the mVRK1-D263G variant. In VRK1-depleted, the CBs were lost, but their assembly was only rescued by the wild-type mVRK1, but not by the mVRK1-D263G loss-of function variant or the kinasedead, mVRK1(K179E) (Figure 3). Therefore, we concluded that in the patients carrying this homozygous variant, the assembly of CBs is defective.

\section{VRK1-D263G Loss-of-Function Variant Impairs the Formation of 53BP1 Foci in Response to DNA Damage}

VRK1 regulates the response to DNA damage, and its depletion impairs the assembly of 53BP1 foci induced by ionizing radiation or doxorubicin. ${ }^{18,19}$ Therefore, we studied the effect of the VRK1-D263G variant on the response to DNA damage induced by doxorubicin. For this aim, we generated stable cell lines in A549 cells that express the mVRK1, the variant (mVRK1-D263G), and the kinase-dead protein (mVRK1-K179E) as control. In these stable cells lines, the human endogenous VRK1 was depleted with 2 different siRNA and followed by treatment with doxorubicin to induce DNA damage, which was detected by formation of 53BP1 foci. In control cells or in the cells in which the wild-type mVRK1 was used, the murine gene rescued the formation of

Figure 2 Kinase Assay of the VRK1-D263G Loss-of-Function Variant With Different Substrates

A

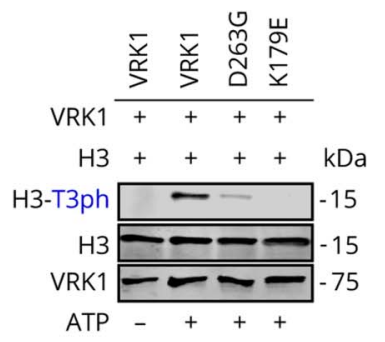

D

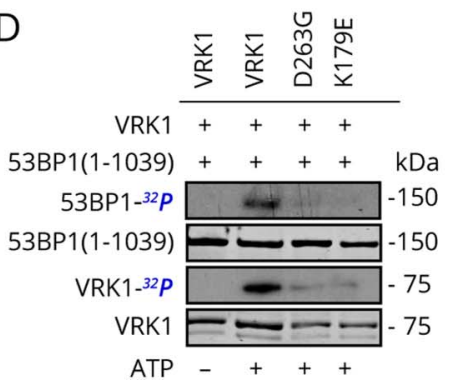

B

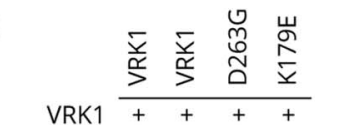

$\mathrm{H} 2 \mathrm{~A} . \mathrm{X}++++\mathrm{kDa}$

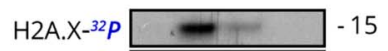

H2A.X -15

VRK1-32P -

VRK1 $=-75$

E
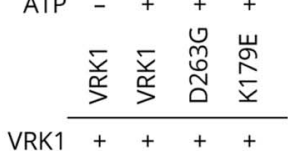

Coilin (160-214) $++++\mathrm{kDa}$

Coilin-32P -25

Coilin (160-214) -25

VRK1-32P -75

VRK1 $=-75$
C

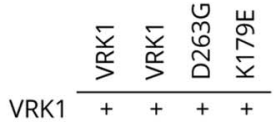

$\mathrm{p} 53(1-84)++++\mathrm{kDa}$

p53 (1-84)-T18ph - 37

p53 (1-84) - 37

VRK1 -75

$\mathrm{F}$

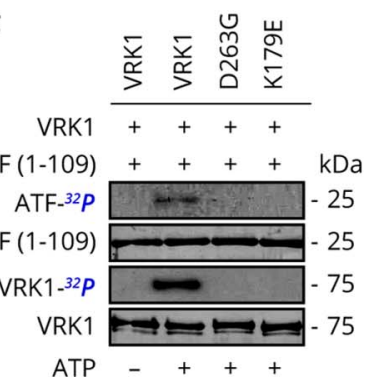

In all assays, a control was included with a kinase-dead vaccinia-related kinase 1-K179E protein and the indicated substrate. (A) Histone $\mathrm{H3}$. (B) Histone $\mathrm{H} 2 \mathrm{AX}$. (C) TP53. (D) p53 binding protein 1. (E) Coilin. (F) Activating transcription factor 2. 


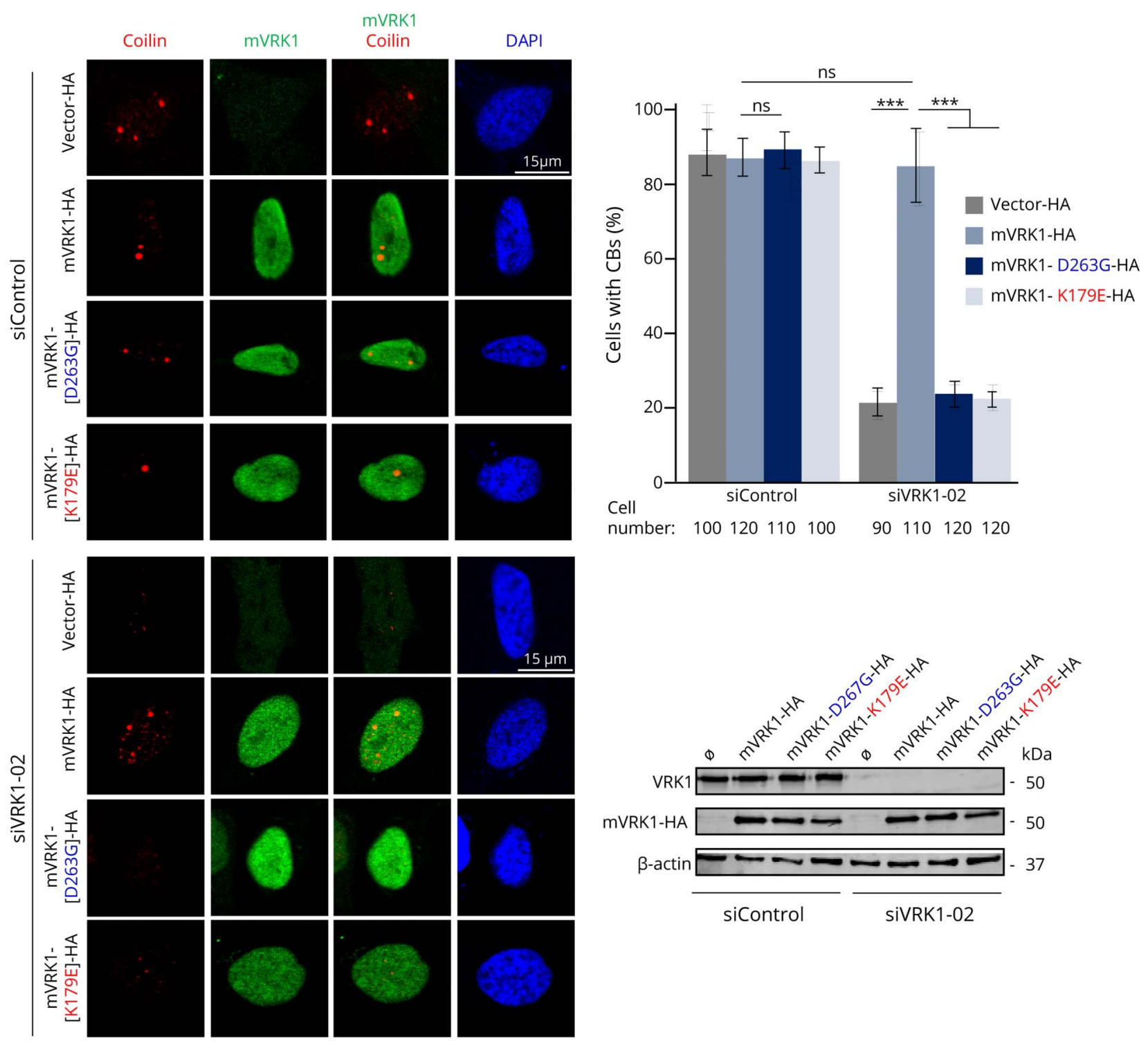

Endogenous human VRK1 was depleted in Hela cells followed by transfection with plasmids expressing murine wild-type mVRK1, mVRK1-D263G, or kinasedead mVRK1-K179E. In cells expressing the transfected murine construct, tagged with the HA epitope, the presence of CBs was determined. CBs were detected by immunofluorescence. The quantification of cells with CBs is shown in the graph. ns: not significant. *** $p<0.001$. The human and murine proteins were detected by immunoblot. CBs = Cajal bodies, mVRK1 = murine VRK1, VRK1 = vaccinia-related kinase 1.

53BP1 foci (Figure 4, left). However, the mutant mVRK1D263G, after depletion of the endogenous human VRK1, was unable to rescue 53BP1 foci formation in response to doxorubicin (Figure 4, right) and behaved like the kinase-dead mVRK1(K179E). These results indicated that the VRK1D263G mutant is unable to respond to DNA damage.

\section{Discussion}

We have identified and functionally validated a novel pathogenic homozygous variant in the VRK1 gene, associated with a novel phenotype comprising HSP and intellectual disability. Functionally, the role of VRK1 variants has to be interpreted in the context of the protein complexes in which the VRK1 protein is integrated and in which some of its components are regulated by this kinase. Particularly, if these interacting or phosphorylation targets are also proteins already known to be implicated in neurologic phenotypes. In this context, the regulation of coilin, the scaffold of CBs, by VRK1 might be a common central mechanisms. Among the components of CBs are survival of motorneuron (SMN) associated with $\mathrm{SMA}^{38}$ ataxin associated with motor coordination alterations, ${ }^{39}$ and some aminoacyl-tRNA synthetase, such as glycyl tRNA synthetase which is associated with some forms of $\mathrm{CMT}^{40}$ The heterogeneity of the phenotypes can be a consequence of the VRK1 variant itself and its effect on the different protein complexes in which it participates. This 
Figure 4 The VRK1-D263G Loss-of-Function Mutant Does Not Rescue 53BP1 Foci Induced by DNA Damage
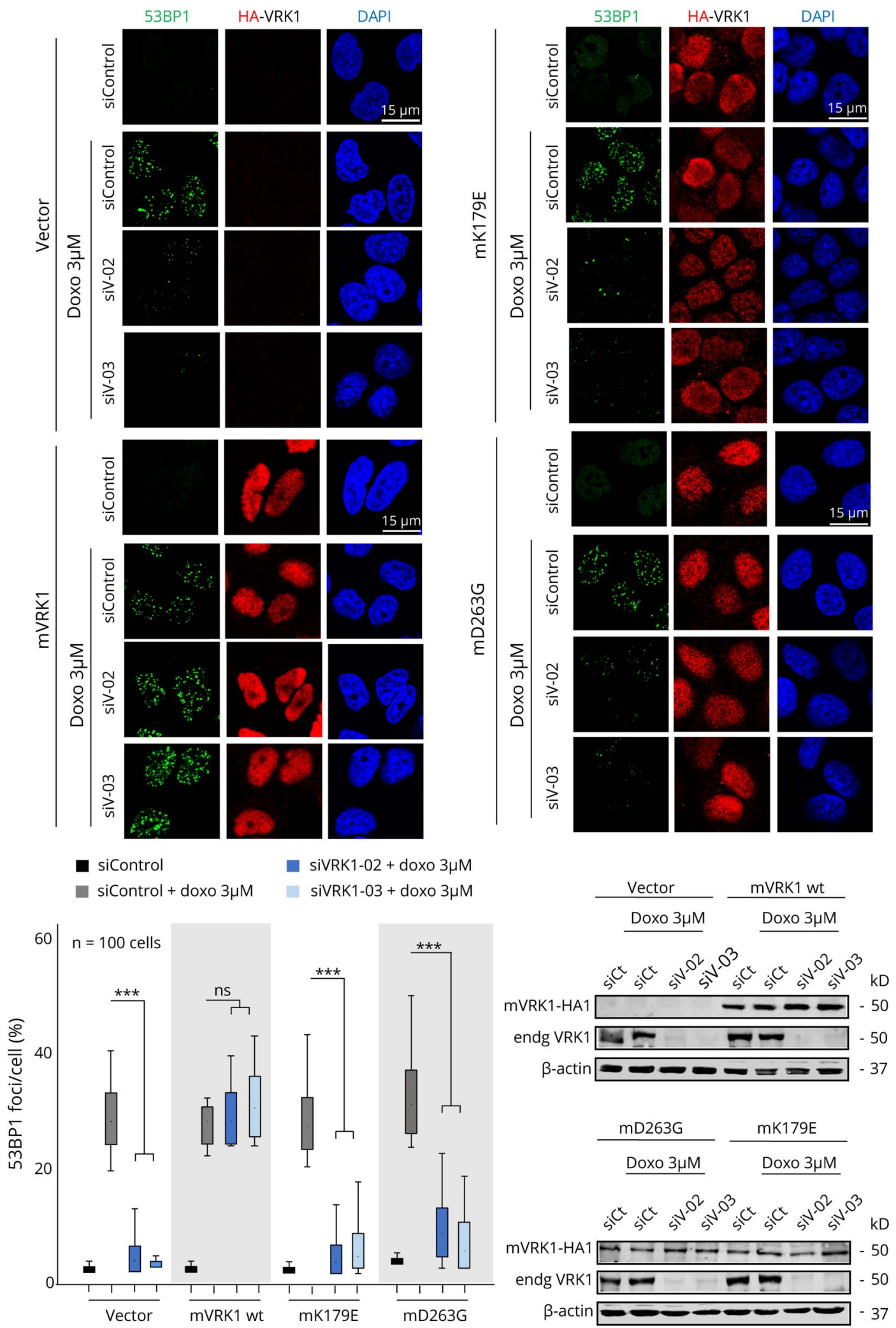

Human stable A549 cell lines expressing murine VRK1 (wt, D263G or K179E) were depleted of the endogenous human VRK1 with two different siRNA. Cells were treated with doxorubicin to induce 53BP1 foci. The immunofluorescence images show the 53BP1 foci. The graphs show the mean number, confidence intervals, and percentiles of 53BP1 foci per cell. The immunoblots show the expression of the different VRK1 proteins in these cells. *** $<<0.001 .53 B P 1=p 53$ binding protein 1; ns = not significant; VRK1 = vaccinia-related kinase 1. 
heterogeneity can also be modulated by the presence of variants in other proteins that participate in these complexes. Some of them can be related to the alteration in CB functions. The loss of coilin can alter its interactions, and functions, with SMN involved in SMA, valosin containing protein implicated in ALS, or proteins such as glycyl tRNA synthetase involved in some forms of CMT.

The VRK1-D263G variant causes a loss of CB assembly, an effect shared with most of the known VRK1 pathogenic variants. $^{22}$ Residual CBs in coilin knock-out mice fail to recruit small nuclear ribonucleoprotein and $\mathrm{SMN}^{41}$ with which coilin forms a bridge. ${ }^{42}$ A recent study has shown that the compound heterozygous VRK1 (R291I, W254L) mutations alter CBs formation in motor neurons. ${ }^{21}$ Furthermore, the VRK1 (R358X) mutant alters neuronal migration that is amyloid-beta precursor protein 1 dependent. ${ }^{23}$

Another pathogenic factor is represented by alterations in DNA damage response (DDR) genes that are associated with several neurologic and neurodevelopmental phenotypes. ${ }^{43}$ HSP paraplegia is caused by pathogenic variants in numerous genes, mainly associated with pathways involved in lipid metabolism, endosomal trafficking, and mitochondrial regulation. ${ }^{44}$ Only 1 gene $(A P 5 Z 1 / S P G 48)^{45}$ has been associated with DNA repair. ${ }^{46}$ This protein is very abundant in nuclei and affects the motor neuron, ${ }^{3}$ but it is normal in these in these patients. An important component of the phenotype can be due to the role of the VRK1 variant in $\mathrm{DDR}^{31}$ as it occurs with most of the VRK1 variants identified in patients with motor neuron diseases. ${ }^{4,8,22}$ Among the proteins implicated in DDR, 4 are direct phosphorylation targets of VRK1. VRK1 regulates $\mathrm{H} 2 \mathrm{AX},{ }^{17}$ Nijmegen breakage syndrome 1 (nibrin), ${ }^{36} 53 \mathrm{BP} 1,{ }^{18} \mathrm{p} 53,{ }^{13,15}$ and 53BP1. ${ }^{18,31}$ These proteins are not phosphorylated by the variant VRK1-D263G, and therefore, DDR response is defective, as shown by the lack of $53 \mathrm{BP} 1$ foci formation in response to DNA damage.

An alternative implication of VRK1 might be a consequence of the loss of ATF2 activation, a transcription factor involved in neurodegeneration and neurogenesis, ${ }^{47}$ which regulates neuronal survival ${ }^{48}$ by playing a protective role. ${ }^{49}$ Pathogenically, ATF2 also can have a role on axonopathies. ${ }^{50}$ In a murine model, the loss of ATF2 causes motor neuron degeneration. ${ }^{34}$

The heterogeneity of the neurologic phenotype among different patients suggests that it may have 2 different pathogenic components. One is the heterogeneity of the VRK1 variant, or mutation, that although the protein complexes in which VRK1 participates is affected, the effect might vary depending on specific protein interactions or levels. Furthermore, this clinical heterogeneity is likely to be determined by the combination with variants in other genes in the patients, which have not been identified. In this context, homozygous variant VRK1-R358X has different clinical phenotypes. In 1 family, the patient had SMA and pontocerebellar hypoplasia $(\mathrm{PCH} 1),{ }^{4}$ whereas in an unrelated family, the patient bore muscular atrophy and progressive hypotonia with decreased deep tendon reflexes, severe nonprogressive microcephaly, but normal intellectual development and no PCH1. ${ }^{51}$ The clinical heterogeneity among patients with homozygous or compound heterozygous VRK1 variants suggests that the observed neuromotor phenotype has to be modulated by variants in other genes that cooperate with VRK1 and which have not been identified.

In conclusion, our study has identified an additional neuromotor phenotype, HSP, associated with a new VRK1 pathogenic variant. VRK1 pathogenic variants cause several motor neuron diseases such as SMA, CMT, HSP, and ALS, with a variable clinical phenotype, both in type and severity. This clinical heterogeneity of VRK1 neuromotor phenotypes is likely to be determined by its cooperation with other genes.

\section{Acknowledgment}

The computational support of the "Centro de Computación Científica CCC-UAM” is gratefully recognized.

\section{Study Funding}

P. M-G. was supported by Ministerio de Educación-FPU predoctoral fellowship (FPU16/01883). This work was funded by grants from Agencia Estatal de Investigación/ Ministerio de Ciencia e Innovación (PID2019-105610RBI00) and Consejería de Educación-Junta de Castilla y León (CSI264P20) to P.A.L. Agencia Estatal de InvestigaciónMinisterio de Ciencia, Innovación y Universidades (RTC2017-6494-1 and RTI2018-094434-B-I00) and European Commission project "CONNECT-JPIAMR Virtual Research Institute” to P.G-P. The Instituto de Biología Molecular y Celular del Cancer is funded by a grant from Junta de Castilla y León-FEDER (CLC-2017-01).

\section{Disclosure}

The authors declare that they have no conflicts of interest. Go to Neurology.org/NG for full disclosures.

\section{Publication History}

Received by Neurology: Genetics June 2, 2021. Accepted in final form July 26, 2021.

Appendix Authors

\begin{tabular}{|c|c|c|}
\hline Name & Location & Contribution \\
\hline $\begin{array}{l}\text { Patricia } \\
\text { Morejon- } \\
\text { Garcia, } \\
\text { MSc }\end{array}$ & $\begin{array}{l}\text { Instituto de Biología } \\
\text { Molecular y Celular del } \\
\text { Cáncer (CSIC)- Universidad de } \\
\text { Salamanca, Salamanca, Spain } \\
\text { Instituto de Investigación } \\
\text { Biomédica de Salamanca } \\
\text { (IBSAL), Hospital Universitario } \\
\text { de Salamanca, Salamanca, } \\
\text { Spain }\end{array}$ & $\begin{array}{l}\text { Performed all the } \\
\text { biochemical and cell biology } \\
\text { experiments }\end{array}$ \\
\hline $\begin{array}{l}\text { Boris } \\
\text { Keren, PhD }\end{array}$ & $\begin{array}{l}\text { Genetics Department, La } \\
\text { Pitié-Salpêtrière Hospital, } \\
\text { APHP. Sorbonne Université, } \\
\text { Paris, France }\end{array}$ & $\begin{array}{l}\text { Performed the WES study and } \\
\text { sequence confirmation }\end{array}$ \\
\hline
\end{tabular}


Appendix (continued)

\begin{tabular}{|c|c|c|}
\hline Name & Location & Contribution \\
\hline $\begin{array}{l}\text { Iñigo } \\
\text { Marcos- } \\
\text { Alcalde, } \\
\text { PhD }\end{array}$ & $\begin{array}{l}\text { Molecular Modelling Group, } \\
\text { Centro de Biología Molecular } \\
\text { "Severo Ochoa". CSIC- } \\
\text { Universidad Autónoma de } \\
\text { Madrid, Spain } \\
\text { Biosciences Research } \\
\text { Institute, School of } \\
\text { Experimental Sciences, } \\
\text { Universidad Francisco de } \\
\text { Vitoria, Pozuelo de Alarcón, } \\
\text { Madrid, Spain }\end{array}$ & $\begin{array}{l}\text { Performed the structural } \\
\text { modeling }\end{array}$ \\
\hline $\begin{array}{l}\text { Paulino } \\
\text { Gomez- } \\
\text { Puertas, } \\
\text { PhD }\end{array}$ & $\begin{array}{l}\text { Molecular Modelling Group, } \\
\text { Centro de Biología Molecular } \\
\text { "Severo Ochoa". CSIC- } \\
\text { Universidad Autónoma de } \\
\text { Madrid, Spain }\end{array}$ & $\begin{array}{l}\text { Performed the structural } \\
\text { modeling }\end{array}$ \\
\hline $\begin{array}{l}\text { Fanny } \\
\text { Mochel, } \\
\text { MD, PhD }\end{array}$ & $\begin{array}{l}\text { Sorbonne Université - } \\
\text { Université Pierre et Marie } \\
\text { Curie, Institut du Cerveau et } \\
\text { de la Moelle épinière, INSERM } \\
\text { U-1127, CNRS-UMR 7225, } \\
\text { Paris, France. }\end{array}$ & $\begin{array}{l}\text { Coordinated the genetic and } \\
\text { clinical study }\end{array}$ \\
\hline $\begin{array}{l}\text { Pedro A. } \\
\text { Lazo, MD, } \\
\text { PhD }\end{array}$ & $\begin{array}{l}\text { Instituto de Biología } \\
\text { Molecular y Celular del } \\
\text { Cáncer (CSIC)- Universidad de } \\
\text { Salamanca, Salamanca, Spain } \\
\text { Instituto de Investigación } \\
\text { Biomédica de Salamanca } \\
\text { (IBSAL), Hospital Universitario } \\
\text { de Salamanca, Salamanca, } \\
\text { Spain }\end{array}$ & $\begin{array}{l}\text { Coordinated and designed } \\
\text { the experimental } \\
\text { characterization of the } \\
\text { variant and wrote the } \\
\text { manuscript. }\end{array}$ \\
\hline
\end{tabular}

\section{References}

1. Murala S, Nagarajan E, Bollu PC. Hereditary spastic paraplegia. Neurol Sci. 2021; 42(3):883-894.

2. Shribman S, Reid E, Crosby AH, Houlden H, Warner TT. Hereditary spastic paraplegia: from diagnosis to emerging therapeutic approaches. Lancet Neurol. 2019; 18(12):1136-1146.

3. Blackstone C, O'Kane CJ, Reid E. Hereditary spastic paraplegias: membrane traffic and the motor pathway. Nat Rev Neurosci. 2011;12(1):31-42.

4. Renbaum P, Kellerman E, Jaron R, et al. Spinal muscular atrophy with pontocerebellar hypoplasia is caused by a mutation in the VRK1 gene. Am J Hum Genet. 2009;85(2) 281-289.

5. Li N, Wang $\mathrm{L}$, Sun $\mathrm{X}$, et al. A novel mutation in VRK1 associated with distal spinal muscular atrophy. J Hum Genet. 2019;64(3):215-219.

6. Sedghi M, Moslemi AR, Olive M, et al. Motor neuron diseases caused by a novel VRK1 variant-a genotype/phenotype study. Ann Clin Transl Neurol. 2019;6(11): 2197-2204.

7. Nguyen TP, Biliciler S, Wiszniewski W, Sheikh K. Expanding phenotype of VRK1 mutations in motor neuron disease. J Clin Neuromuscul Dis. 2015;17(2):69-71.

8. Marcos AT, Martín-Doncel E, Morejón-García P, et al. VRK1 (Y213H) homozygous mutant impairs Cajal bodies in a hereditary case of distal motor neuropathy. Ann Clin Transl Neurol. 2020;7(5):808-818.

9. Feng SY, Li LY, Feng SM, Zou ZY. A novel VRK1 mutation associated with recessive distal hereditary motor neuropathy. Ann Clin Transl Neurol. 2019;6(2):401-405.

10. Valbuena A, López-Sánchez I, Lazo PA. Human VRK1 is an early response gene and its loss causes a block in cell cycle progression. Plos One. 2008;3(2):e1642.

11. Kim YS, Kim SH, Shin J, et al. Luteolin suppresses cancer cell proliferation by targeting vaccinia-related kinase 1. Plos One. 2014;9(10):e109655.

12. Sevilla A, Santos CR, Vega FM, Lazo PA. Human vaccinia-related kinase 1 (VRK1) activates the ATF2 transcriptional activity by novel phosphorylation on Thr-73 and Ser-62 and cooperates with JNK. J Biol Chem. 2004;279(26):27458-27465.

13. Vega FM, Sevilla A, Lazo PA. p53 Stabilization and accumulation induced by human vaccinia-related kinase 1. Mol Cell Biol. 2004;24(23):10366-10380.

14. Sevilla A, Santos CR, Barcia R, Vega FM, Lazo PA. c-Jun phosphorylation by the human vaccinia-related kinase 1 (VRK1) and its cooperation with the $\mathrm{N}$-terminal kinase of c-Jun (JNK). Oncogene. 2004;23(55):8950-8958.

15. Valbuena A, Vega FM, Blanco S, Lazo PA. p53 downregulates its activating vacciniarelated kinase 1, forming a new autoregulatory loop. Mol Cell Biol. 2006;26(13): $4782-4793$.
16. Kang TH, Park DY, Choi YH, Kim KJ, Yoon HS, Kim KT. Mitotic histone H3 phosphorylation by vaccinia-related kinase 1 in mammalian cells. Mol Cell Biol. 2007; 27(24):8533-8546.

17. Salzano M, Sanz-García M, Monsalve DM, Moura DS, Lazo PA. VRK1 chromatin kinase phosphorylates $\mathrm{H} 2 \mathrm{AX}$ and is required for foci formation induced by DNA damage. Epigenetics. 2015;10(5):373-383.

18. Sanz-Garcia M, Monsalve DM, Sevilla A, Lazo PA. Vaccinia-related Kinase 1 (VRK1) is an upstream nucleosomal kinase required for the assembly of 53BP1 foci in response to ionizing radiation-induced DNA damage. J Biol Chem. 2012;287(28): 23757-23768

19. Campillo-Marcos I, Lazo PA. Implication of the VRK1 chromatin kinase in the signaling responses to DNA damage: a therapeutic target? Cell Mol Life Sci. 2018; 75(13):2375-2388.

20. Cantarero L, Sanz-García M, Vinograd-Byk H, Renbaum P, Levy-Lahad E, Lazo PA VRK1 regulates Cajal body dynamics and protects coilin from proteasomal degradation in cell cycle. Sci Rep. 2015;5(1):10543.

21. El-Bazzal L, Rihan K, Bernard-Marissal N, et al. Loss of Cajal bodies in motor neurons from patients with novel mutations in VRK1. Hum Mol Genet. 2019;28(14): 2378-2394.

22. Martin-Doncel E, Rojas AM, Cantarero L, Lazo PA. VRK1 functional insufficiency due to alterations in protein stability or kinase activity of human VRK1 pathogenic variants implicated in neuromotor syndromes. Sci Rep. 2019;9(1):13381.

23. Vinograd-Byk H, Sapir T, Cantarero L, et al. The spinal muscular atrophy with pontocerebellar hypoplasia gene VRK1 regulates neuronal migration through an amyloid-beta precursor protein-dependent mechanism. J Neurosci. 2015;35(3): 936-942.

24. Cingolani P, Platts A, Wang le L, et al. A program for annotating and predicting the effects of single nucleotide polymorphisms, SnpEff: SNPs in the genome of Drosophila melanogaster strain w1118; iso-2; iso-3. Fly (Austin). 2012;6(2):80-92.

25. Marcos-Alcalde I, Mendieta-Moreno JI, Puisac B, et al. Two-step ATP-driven opening of cohesin head. Sci Rep. 2017;7(1):3266.

26. Vazquez-Cedeira M, Barcia-Sanjurjo I, Sanz-Garcia M, Barcia R, Lazo PA. Differential inhibitor sensitivity between human kinases VRK1 and VRK2. Plos One. 2011;6(8): e23235.

27. Lopez-Borges S, Lazo PA. The human vaccinia-related kinase 1 (VRK1) phosphorylates threonine- 18 within the mdm-2 binding site of the p53 tumour suppressor protein. Oncogene. 2000;19(32):3656-3664.

28. Moura DS, Campillo-Marcos I, Vázquez-Cedeira M, Lazo PA. VRK1 and AURKB form a complex that cross inhibit their kinase activity and the phosphorylation of histone H3 in the progression of mitosis. Cell Mol Life Sci. 2018;75(14):2591-2611.

29. Lopez-Sanchez I, Valbuena A, Vazquez-Cedeira M, et al. VRK1 interacts with p53 forming a basal complex that is activated by UV-induced DNA damage. FEBS Lett. 2014:588(5):692-700.

30. Santos CR, Vega FM, Blanco S, Barcia R, Lazo PA. The vaccinia virus B1R kinase induces p53 downregulation by an Mdm2-dependent mechanism. Virology. 2004; 328(2):254-265

31. Campillo-Marcos I, Lazo PA. Olaparib and ionizing radiation trigger a cooperative DNA-damage repair response that is impaired by depletion of the VRK1 chromatin kinase. J Exp Clin Cancer Res. 2019;38(1):203.

32. Hebert MD, Szymczyk PW, Shpargel KB, Matera AG. Coilin forms the bridge between Cajal bodies and SMN, the spinal muscular atrophy protein. Genes Dev. 2001; $15(20): 2720-2729$

33. Sanz-Garcia M, Vazquez-Cedeira M, Kellerman E, Renbaum P, Levy-Lahad E, Lazo PA. Substrate profiling of human vaccinia-related kinases identifies coilin, a Cajal body nuclear protein, as a phosphorylation target with neurological implications. J Proteomics. 2011;75(2):548-560.

34. Ackermann J, Ashton G, Lyons S, et al. Loss of ATF2 function leads to cranial motoneuron degeneration during embryonic mouse development. Plos One. 2011; 6(4):e19090.

35. Delcroix JD, Averill S, Fernandes K, Tomlinson DR, Priestley JV, Fernyhough P. Axonal transport of activating transcription factor- 2 is modulated by nerve growth factor in nociceptive neurons. J Neurosci. 1999;19(18):RC24.

36. Monsalve DM, Campillo-Marcos I, Salzano M, Sanz-García M, Cantarero L, Lazo PA. VRK1 phosphorylates and protects NBS1 from ubiquitination and proteasomal degradation in response to DNA damage. Biochim Biophys Acta. 2016;1863(4): 760-769.

37. Hebert MD, Matera AG. Self-association of coilin reveals a common theme in nuclear body localization. Mol Biol Cell. 2000;11(12):4159-4171.

38. Toyota CG, Davis MD, Cosman AM, Hebert MD. Coilin phosphorylation mediates interaction with SMN and SmB'. Chromosoma. 2010;119(2):205-215.

39. Hong S, Ka S, Kim S, Park Y, Kang S. p80 coilin, a coiled body-specific protein, interacts with ataxin-1, the SCA1 gene product. Biochim Biophys Acta. 2003;1638(1) $35-42$.

40. Lee DC, Meyer-Schuman R, Bacon C, Shy ME, Antonellis A, Scherer SS. A recurrent GARS mutation causes distal hereditary motor neuropathy. J Peripher Nerv Syst. 2019; 24(4):320-342.

41. Tucker KE, Berciano MT, Jacobs EY, et al. Residual Cajal bodies in coilin knockout mice fail to recruit Sm snRNPs and SMN, the spinal muscular atrophy gene product. J Cell Biol. 2001;154(2):293-307.

42. Nizami Z, Deryusheva S, Gall JG. The Cajal body and histone locus body. Cold Spring Harb Perspect Biol. 2010;2(7):a000653.

43. McKinnon PJ. Maintaining genome stability in the nervous system. Nat Neurosci. 2013;16(11):1523-1529. 
44. Noreau A, Dion PA, Rouleau GA. Molecular aspects of hereditary spastic paraplegia. Exp Cell Res. 2014;325(1):18-26.

45. Hirst J, Madeo M, Smets K, et al. Complicated spastic paraplegia in patients with AP5Z1 mutations (SPG48). Neurol Genet. 2016;2(5):e98.

46. Słabicki M, Theis M, Krastev DB, et al. A genome-scale DNA repair RNAi screen identifies SPG48 as a novel gene associated with hereditary spastic paraplegia. Plos Biol. 2010;8(6):e1000408.

47. Pearson AG, Curtis MA, Waldvogel HJ, Faull RL, Dragunow M. Activating transcription factor 2 expression in the adult human brain: association with both neurodegeneration and neurogenesis. Neuroscience. 2005;133(2): 437-451.
48. Esvald EE, Tuvikene J, Sirp A, Patil S, Bramham CR, Timmusk T. CREB family transcription factors are major mediators of BDNF transcriptional autoregulation in cortical neurons. J Neurosci. 2020;40(7):1405-1426.

49. Welsbie DS, Mitchell KL, Jaskula-Ranga V, et al. Enhanced functional genomic screening identifies novel mediators of dual leucine zipper kinase-dependent injury signaling in neurons. Neuron. 2017;94(6):1142.e6-1154.e6.

50. Dapper JD, Crish SD, Pang IH, Calkins DJ. Proximal inhibition of p38 MAPK stress signaling prevents distal axonopathy. Neurobiol Dis. 2013;59:26-37.

51. Gonzaga-Jauregui C, Lotze T, Jamal L, et al. Mutations in VRK1 associated with complex motor and sensory axonal neuropathy plus microcephaly. JAMA Neurol. 2013;70(12):1491-1498. 


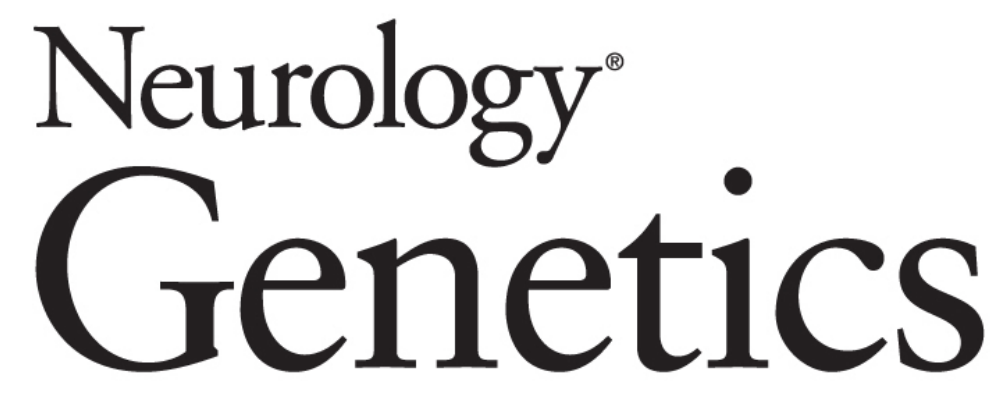

\section{Dysfunctional Homozygous VRK1-D263G Variant Impairs the Assembly of Cajal Bodies and DNA Damage Response in Hereditary Spastic Paraplegia \\ Patricia Morejon-Garcia, Boris Keren, Iñigo Marcos-Alcalde, et al. \\ Neurol Genet 2021;7; \\ DOI 10.1212/NXG.0000000000000624}

This information is current as of September 2, 2021

Updated Information \& Services

References

Subspecialty Collections

Permissions \& Licensing

Reprints including high resolution figures, can be found at: http://ng.neurology.org/content/7/5/e624.full.html

This article cites 51 articles, 13 of which you can access for free at: http://ng.neurology.org/content/7/5/e624.full.html\#\#ref-list-1

This article, along with others on similar topics, appears in the following collection(s):

All Genetics

http://ng.neurology.org//cgi/collection/all_genetics

All Neuromuscular Disease

http://ng.neurology.org//cgi/collection/all_neuromuscular_disease

Developmental disorders

http://ng.neurology.org//cgi/collection/developmental_disorders

Spastic paraplegia

http://ng.neurology.org//cgi/collection/spastic_paraplegia

Information about reproducing this article in parts (figures,tables) or in its entirety can be found online at:

http://ng.neurology.org/misc/about.xhtml\#permissions

Information about ordering reprints can be found online:

http://ng.neurology.org/misc/addir.xhtml\#reprintsus

Neurol Genet is an official journal of the American Academy of Neurology. Published since April 2015, it is an open-access, online-only, continuous publication journal. Copyright Copyright $\odot 2021$ The Author(s). Published by Wolters Kluwer Health, Inc. on behalf of the American Academy of Neurology.. All rights reserved. Online ISSN: 2376-7839.

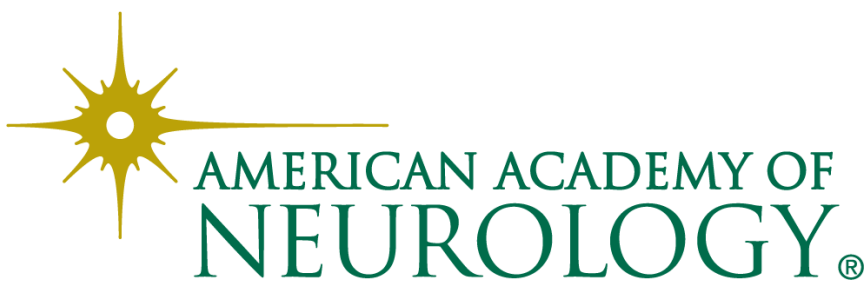

